\title{
STRAIN HARDENING OF FLAT SAMPLES OF TWO-DIMENSIONAL HIGH PURITY AI POLYCRYSTALS
}

\author{
E.E. Badiyan, A.G. Tonkopryad, Ye.V. Ftomov, O.V. Shekhovtsov \\ V.N. Karazin Kharkiv National University, Kharkiv, Ukraine \\ E-mail: Evgeny.E.Badiyan@univer.kharkov.ua; tel. +38(057)707-53-47
}

Using the dislocation-kinetic approach based on equations describing the evolution of the average dislocation density in a material with an increase in shear strain, size effects have been theoretically studied that are associated with the effect on the strain hardening of the sample of the average grain size $d_{s}$ and thickness $D$ and are caused by the dependence of the kinetic equation terms on $d_{s}$ and $D$. Established in a common way using the Taylor relation and experimentally confirmed the relationship between the flow stress $\sigma$ and the strain degree $\varepsilon$ was used to analyze the strain hardening of flat samples of two-dimensional high-purity Al polycrystals with different grain sizes in the range $\sim 50 \mu \mathrm{m}<d_{s}<\sim 1 \mathrm{~mm}$ and various thicknesses in the range of $\sim 50 \mu \mathrm{m}<D<\sim 1$ mm under uniaxial tension with a constant strain rate at moderate temperatures. It was shown that the dependence of the offset yield strenght $\sigma_{0.2}$ on the grain size $d_{s}$ almost vanishes at $d_{s}>300 \mu \mathrm{m}$. It was found that the values of $\sigma_{0.2}$ and the strainhardening coefficient $\theta=d \sigma / d \varepsilon$ decrease with increasing thickness $D$ of the sample. These decreasing dependences are replaced by increasing ones with increasing degree of deformation. Stress $\sigma$ and coefficient $\theta$ increase with increasing ratio $D / d_{s}$ at all stages of deformation.

PACS: 61.72.Cc, 61.82.Bg, 62.20.Fe

\section{INTRODUCTION}

The mechanical characteristics of polycrystals of metals depend both on the grain size and on the transverse size (thickness or diameter) of the deformed samples. Two size effects, one of which is associated with the influence of the grain size $d$, and the other one with the transverse size $D$ can be detected in one sample. In [1], the effect of the average grain size and thickness of the samples on the mechanical characteristics of flat polycrystalline samples of pure (99.99 wt.\%) aluminum $6 \mathrm{~mm}$ wide, from 0.045 to $1.840 \mathrm{~mm}$ thick with different average grain sizes (from 16 to $\left.180^{\circ} \mu \mathrm{m}\right)$ were experimentally studied. In [2], experimental studies of the mechanical behavior under uniaxial tension of samples of pure (99.999 at.\%) aluminum $30 \mathrm{~mm}$ long, $4 \mathrm{~mm}$ wide, from 100 to $340 \mu \mathrm{m}$ thick with various average grain sizes from 75 to $480^{\circ} \mu \mathrm{m}$ were carried out. Such samples had in cross section from one to several grain layers. In [3], using the dislocation-kinetic approach, the effects of decreasing strength and deviations from the Hall-Petch ratio during plastic deformation of samples with a micro- and nanograin structure with a decrease in their transverse size were theoretically studied, and the effect of reducing the strength of submicro-sized samples was studied in [4] for samples of FCC metals with a nanocrystalline structure with a sample cross section $D<5 d$. This approach was applied in [5] to the description of strain hardening under uniaxial tension with a constant strain rate at moderate temperatures of flat samples of two-dimensional high-purity aluminum polycrystals with different grain sizes in the range $\sim 50 \mu \mathrm{m}<d_{s}<\sim 1 \mathrm{~mm}$ and various thicknesses in the range $\sim 50 \mu \mathrm{m}<D<\sim 1 \mathrm{~mm}$, containing only one layer of grains and having grain boundaries through the thickness of the sample. In [5], the coefficients of the dislocation-kinetic equation were calculated, which describes the evolution of the dislocation density in a material with an increase in the degree of plastic deformation [3, 6, 7] and which are took into account the features of the studied flat samples of twodimensional polycrystals of pure metals, in addition an analytical solution was obtained, based on which the deformation curve was calculated. It is of interest to further study using the dislocation-kinetic approach the features of strain hardening of flat samples of twodimensional high-purity aluminum polycrystals due to the influence of grain size and sample thickness.

\section{DISLOCATION-KINETIC DESCRIPTION OF A UNIAXIAL TENSION OF FLAT SAMPLES OF TWO-DIMENSIONAL POLYCRYSTALS OF PURE METALS AT MODERATE TEMPERATURES}

Two-dimensional polycrystals contain only one layer of grains and have through ("vertical") grain boundaries over the thickness of the sample. In such objects, the two free surfaces of each grain coincide with the free surface of the polycrystal, which are play a significant role as a source and sink for dislocations in the case of flat samples, i.e. rectangular samples, the dimensions of which are related by the relation $D \ll w<l$, where $D$ is the thickness of the sample; $w$ and $l$ are the width and length of the working part, respectively, with a large ratio of the free surface area to the volume of the samples $S_{S} / V \gg 1 \mathrm{~cm}^{-1}$. In this case, the grain structure is characterized by the average size $d_{s}$ on the "horizontal" free surface of the sample, i.e. in the plane $(l, w)$, and with a size $d_{t}$ equal to the thickness of the sample $D$. For $d_{s}=d_{t}$, the grain structure is equiaxed in three dimensions. In the case of $d_{s} \ll d_{t}=D$, grains structure called "needle", and in the case of $d_{s} \gg d_{t}=D$, it called "pancake" [2].

For the kinetic equation known from [3, 6, 7], which describes the evolution of the average dislocation density $\rho$ in a material with an increase in shear strain $\gamma$, its coefficients were determined in [5] taking into account the strengthening effect of the "vertical" grain boundaries in a two-dimensional polycrystal and the 
role of the free surface of a flat sample as a source and sink for dislocations during uniaxial tension of pure metal samples with different grain sizes in the range of $\sim 50 \mu \mathrm{m}<d_{s}<\sim 1 \mathrm{~mm}$ and different thicknesses in the range of $\sim 50 \mu \mathrm{m}<D<\sim 1 \mathrm{~mm}$ at moderate temperature

$$
\begin{aligned}
& \rho(d \rho / d \gamma)=\left(\cos \varphi / b d_{s}\right) \rho+(2 / D)\left(n_{S} / b\right)+ \\
& k_{f} \rho^{3 / 2}-(\sin \varphi / b D) \rho-k_{a} \rho^{2},
\end{aligned}
$$

where $\varphi$ is the angle between the slip plane and the tensile axis; $b$ is the Burgers vector; $n_{S}$ is the density of the surface dislocation sources; $k_{f}$ is the coefficient describes the intensity of dislocation multiplication on forest dislocations $\left(k_{f} \approx 10^{-2} / b\right) ; k_{a}$ is the coefficient of annihilation of screw dislocations. To obtain the stress-strain curves $\sigma(\varepsilon)$, kinetic equation (1) was transformed using the expressions $d \gamma=m d \varepsilon, \sigma=m \tau$, where $m$ is the orientation factor and $\tau$ is the flow stress, which is determined by the interaction of dislocations with each other in accordance with the Taylor relation [8] $\tau=\alpha \mu b \rho^{1 / 2}$, in which $\alpha$ is the constant of interaction of dislocations with each other, $\mu$ is the shear modulus, to the form

$\sigma^{3}(d \sigma / d \varepsilon)=-m k_{a}\left(\sigma^{4}+a_{1} \sigma^{3}+a_{2} \sigma^{2}+a_{3}\right) / 2$.

Integration of (2) gives the dependence of the deforming stress $\sigma$ on the degree of plastic deformation $\varepsilon$ in an implicit form [5]

$$
\begin{gathered}
-\left(2 / m k_{a}\right)\left(A_{1} \ln \left|\sigma-\sigma_{1}\right|+A_{2} \ln \left|\sigma-\sigma_{2}\right|+\right. \\
+\left(A_{3} / 2\right) \ln \left|\sigma^{2}+\xi_{1} \sigma+\xi_{2}\right|+ \\
+\left(\left(-\xi_{1} A_{3} / 2+A_{4}\right) / \sqrt{\xi_{2}-\left(\xi_{1} / 2\right)^{2}}\right) \operatorname{arctg}((\sigma+ \\
\left.\left.\left.+\xi_{1} / 2\right) / \sqrt{\xi_{2}-\left(\xi_{1} / 2\right)^{2}}\right)\right)+C=\varepsilon .
\end{gathered}
$$

The new parameters introduced in (2) and (3) are expressed in terms of the coefficients of the kinetic equation (1), and the integration constant $C$ is determined from the condition $\sigma(0)=0$. A quantitative comparison of theory and experiment, performed in [5] using the experimental data from [2] for flat samples of two-dimensional high-purity aluminum polycrystals (99.999 at.\%), showed their fairly good agreement. In the present work, based on the obtained solution (3), the size effects during plastic deformation of the objects discussed above were studied with the same calculation parameters as used in [5], which are $m=2.69$; $\varphi=\pi / 4 ; \quad \mu=27 \mathrm{GPa} ; \quad b=0.286 \mathrm{~nm} ; \quad \alpha=0.32$; $k_{a}=9.7 ; n_{S}=1.00 \mu \mathrm{m}^{-2}$.

\section{SIZE EFFECTS IN FLAT SAMPLES OF TWO-DIMENSIONAL POLYCRYSTALS OF PURE AI UNDER UNIAXIAL TENSION}

In this work, size effects are referred to effects associated with the impact of average grain size $d_{s}$ and thickness $D$ on strain hardening of the samples. The values of the terms contained in the kinetic equation (1) depend on the thickness of the samples. The nature of these dependences is different at the initial stage of deformation $\varepsilon=0.2 \%$ (Fig. 1,a), corresponding to the offset yield strenght $\sigma_{0.2}$, and at a much later stage of deformation $\varepsilon=10 \%$ (see Fig. 1,b).

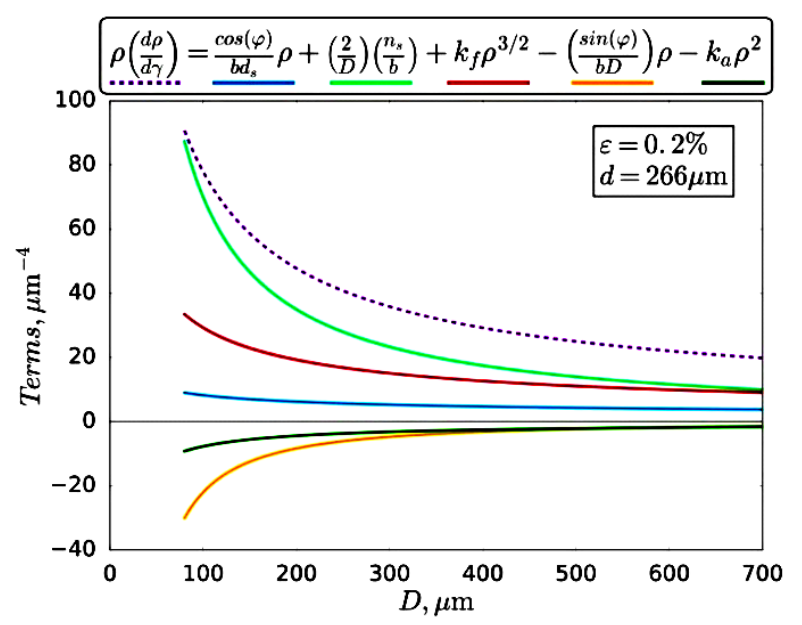

$a$

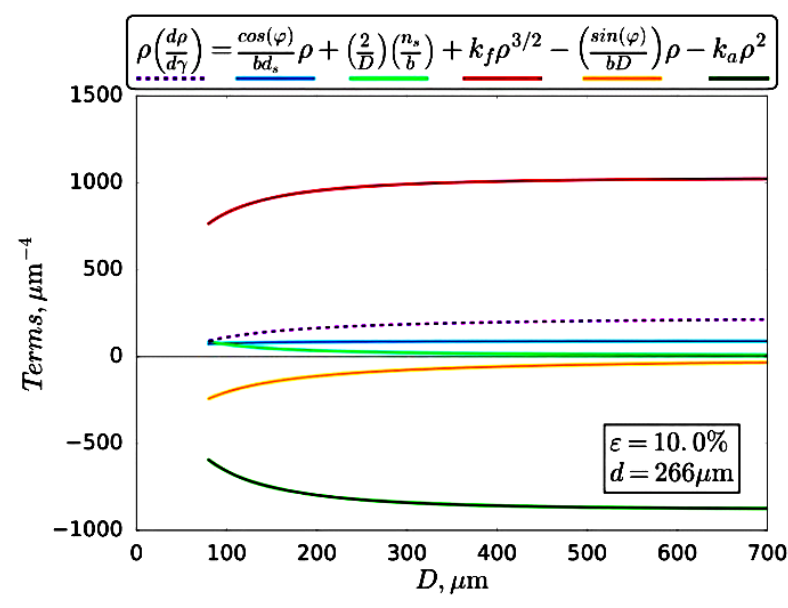

$b$

Fig. 1. Dependences of the values of the terms contained in the kinetic equation (1) on the thickness of the samples at strain values $\varepsilon=0.2 \%(a)$ and $\varepsilon=10 \%(b)$ for a given value of the average grain siz $d_{s}=266 \mu \mathrm{m}$

On the right side of equation (1), the coefficient in the first term depends on the average grain size, which determines the corresponding size effect. The second and fourth terms take into account the role of the free surface of a flat sample as a source and sink for dislocations and describe the size effect, which is associated with the thickness of the sample and arises as a result of competition between the emission of dislocations from surface sources and the egress of dislocations on the surface of the sample [3]. All this affects the strain hardening, which is discussed below.

Fig. 2 illustrates the deviation from the Hall-Petch relation $[9,10]$. The dependence of the offset yield strength $\sigma_{0.2}$, calculated according to (3), on the grain size practically vanishes at $d_{s}>300 \mu \mathrm{m}$ for all studied values of the sample thickness $\sim 50 \mu \mathrm{m}<D<\sim 1 \mathrm{~mm}$. In addition, the offset yield strength decreases with increasing thickness of the sample. 


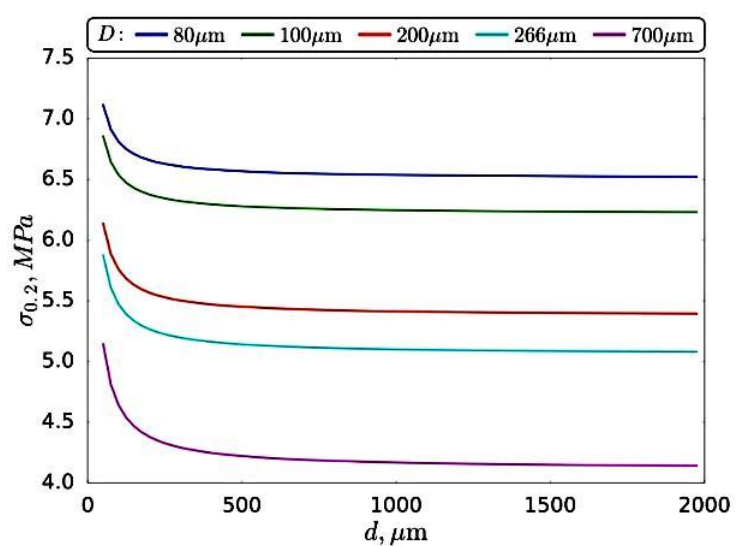

Fig. 2. Dependence of the offset yield strength $\sigma_{0.2}$ on the grain size $d_{s}$ for various values of the sample thickness D

The dependence of the flow stress, calculated according to (3), on the thickness of the sample changes its form with an increase in the degree of deformation (Fig. 3). The dependence $\sigma(D)$ is decreasing at the early stage of deformation $\varepsilon=1 \%$ (see Fig. 3,a), but changes to increasing at a much later stage of deformation $\varepsilon=10 \%$ (see Fig. 3,b). Fig. 3 also shows that the flow stress increases as the grain size decreases.
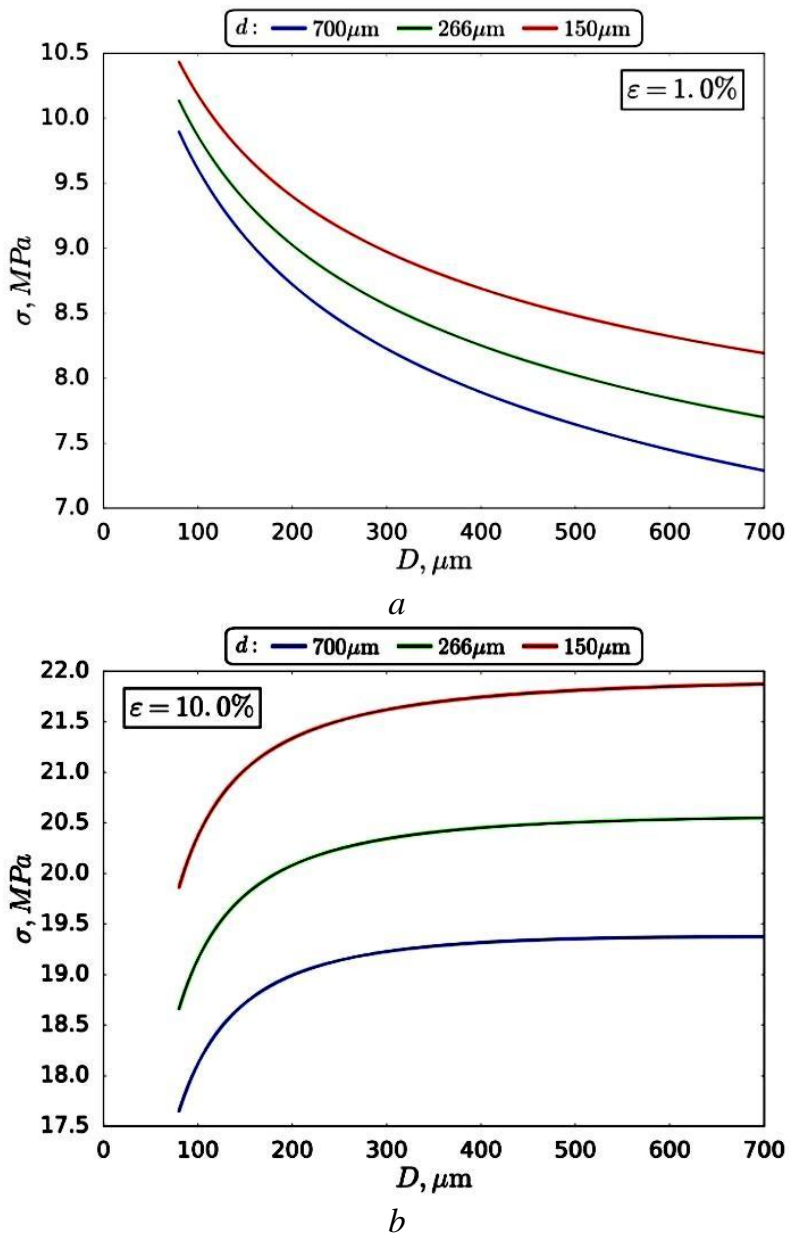

Fig. 3. Dependence of flow stress $\sigma$ on sample thickness $D$ for various grain sizes $d_{s}$ at strain $\varepsilon=1 \%(a)$ and $\varepsilon=10 \%(b)$
The flow stress increases with increasing ratio $D / d_{s}$, the value of which characterizes the proximity of the grain structure to equiaxial, "needle" or "pancake", both at the initial stage of deformation at the level of the offset yield strength $\sigma_{0.2}$ (Fig. 4,a), as well as at the stage of developed strain (see Fig. 4,b). Thus, the flow stress at a given degree of deformation increases with the transition from the "pancake" grain structure to the "needle" structure at all stages of deformation.

The decreasing dependence of the strain-hardening coefficient $\theta=d \sigma / d \varepsilon$, which was calculated in accordance with (2) and (3), on the thickness of the specimen under strain $\varepsilon=0.2 \%$ (Fig. 5,a) is replaced by an increasing one even under strain $\varepsilon=1 \%$ (see Fig. $5, \mathrm{~b}$ ) and remains so with a further increase in the degree of deformation.

Like the flow stress, the strain-hardening coefficient increases with the ratio $D / d_{s}$, i.e. during transition from the "pancake" grain structure to the "needle" one, at all stages of deformation. Fig. 6 illustrates this fact for two values of the degree of deformation.
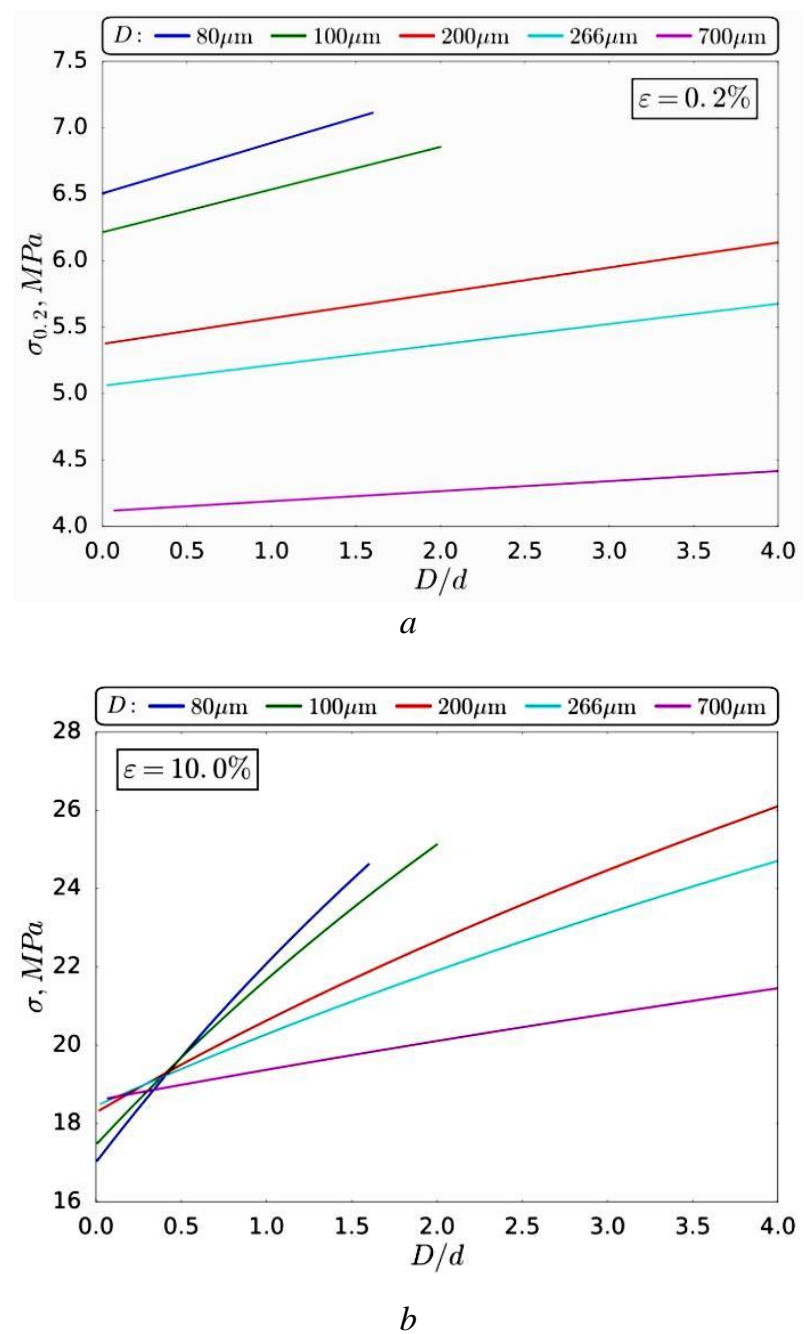

Fig. 4. The dependence of the flow stress $\sigma$ on the ratio $D / d_{s}$ for various values of the sample thickness $D$ at strain $\varepsilon=0.2 \%(a)$ and $\varepsilon=10 \%(b)$ 


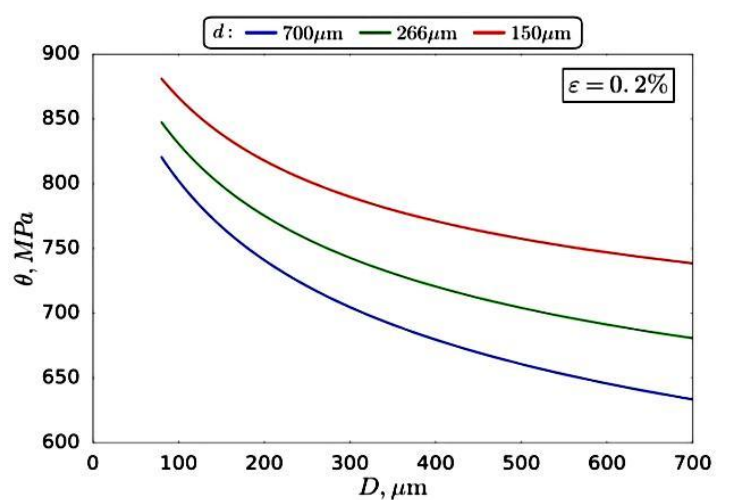

$a$

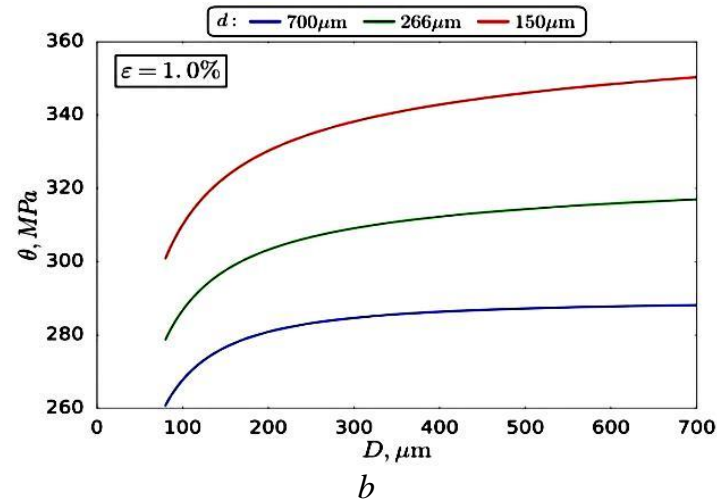

Fig. 5. The dependence of the strain-hardening coefficient $\theta$ on the sample thickness $D$ for various grain sizes $d_{s}$ at strain $\varepsilon=0.2 \%(a)$ and $\varepsilon=1 \%(b)$
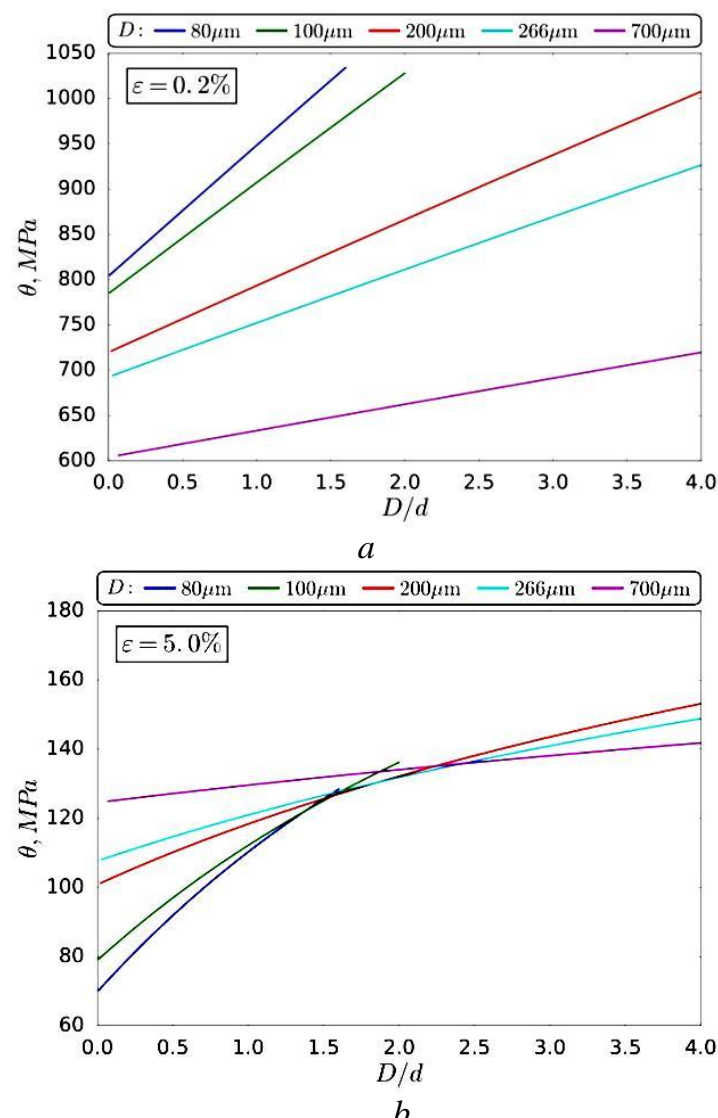

Fig. 6. The dependence of the strain-hardening coefficient $\theta$ on the ratio $D / d_{s}$ for various values of the thickness of the sample $D$ at strain $\varepsilon=0.2 \%(a)$ and $\varepsilon=5 \%(b)$

\section{CONCLUSIONS}

Based on the previously theoretically obtained dependence $\sigma(\varepsilon)$ for flat samples of two-dimensional polycrystals of pure $\mathrm{Al}$, which is a solution of the dislocation-kinetic equation and is in fairly good agreement with experimental data, the influence of grain size (varying in the interval $\sim 50 \mu \mathrm{m}<d_{s}<\sim 1 \mathrm{~mm}$ ) and thickness (changing by more than an order of magnitude, starting from $\sim 50 \mu \mathrm{m}$ ) on the conditional yield strength, deforming stress and strain-hardening coefficient was studied in case of uniaxial tension with a constant speed of deformation at moderate temperatures.

A deviation from the Hall-Petch relation was found; the dependence of the offset yield strength on the grain size almost vanishes at $d_{s}>300 \mu \mathrm{m}$ for the sample thicknesses of $\sim 50 \mu \mathrm{m}<D<\sim 1 \mathrm{~mm}$. It was established that the offset yield strength decreases with increasing thickness of the sample. It is shown that the dependence of deforming stress on thickness of the sample is decreasing at the early stage of deformation $\varepsilon=1 \%$, but it is increasing at the stage of deformation $\varepsilon=10 \%$. The decreasing dependence of the strainhardening coefficient on the sample thickness upon deformation $\varepsilon=0.2 \%$ is replaced by an increasing one, starting from strain $\varepsilon \approx 1 \%$. The flow stress and strainhardening coefficient increase with increasing ratio $D / d_{s}$ during the transition from the "pancake" grain structure to the "needle" structure at all stages of deformation. These size effects, which depend on the grain size and thickness of the sample, are caused by the strengthening action of the vertical grain boundaries in a two-dimensional polycrystal, and the effect on the strain hardening of the free surface of a flat sample, which is the source and sink for dislocations.

\section{REFERENCES}

1. S. Miyazaki, K. Shibata, H. Fujita. Effect of specimen thickness on mechanical properties of polycrystalline aggregates with various grain sizes // Acta Metall. 1979, v. 27, p. 855-862.

2. P.J. Janssen, T.H. de Keijser, M.G. Geers. An experimental assessment of grain size effects in the uniaxial straining of thin $\mathrm{Al}$ sheet with a few grains across the thickness // Mater. Sci. Eng. 2006, v. A 419, p. 238-248.

3. G.A. Malygin. Influence of the transverse size of samples with micro- and nanograined structures on the yield and flow stresses // Phys. Solid State. 2012, v. 54(3), p. 559-567.

4. G.A. Malygin. Mechanism of decrease in the strength of submicron-sized specimens of FCC metals with a nanocrystalline structure // Phys. Solid State. 2017, v. 59(2), p. 321-326.

5. E.E. Badiyan, A.G. Tonkopryad, Ye.V. Ftomov, O.V. Shekhovtsov. Dislocation kinetics during plastic deformation of two-dimensional polycrystals // Problems of Atomic Science and Technology. Series "Radiation Damage Physics and Radiation Materials Science”. 2019, N 2(120), p. 25-29. 
6. G.A. Malygin. Strength and plasticity of nanocrystalline materials and nanosized crystals // Phys. Usp. 2011, v. 54(11), p. 1091-1116.

7. U.F. Kocks, H. Mecking. Physics and phenomenology of strain hardening: the FCC case // Progr. Mater. Sci. 2003, v. 48, p. 171-273.

8. G.I. Taylor. The mechanism of plastic deformation of crystals. Part I. Theoretical // Proc. Roy. Soc. A. 1934, v. 145, N 855, p. 362-387.
9. E.O. Hall. The deformation and ageing of mild steel: III Discussion of results // Proc. Phys. Soc. B. 1951, v. 64, N 9, p. 747-753.

10. N.J. Petch. The cleavage strength of polycrystals // Journ. Iron Steel Inst. 1953, v. 174, p. 25-28.

Статья поступила в редакциию 18.10.2019 2.

\title{
ДЕФОРМАЦИОННОЕ УПРОЧНЕНИЕ ПЛОСКИХ ОБРАЗЦОВ ДВУМЕРНЫХ ПОЛИКРИСТАЛЛОВ АІ ВЫСОКОЙ ЧИСТОТЫ
}

\author{
Е.Е. Бадиян, А.Г. Тонкопряд, Е.В. Фтёмов, О.В. Шеховцов
}

С использованием дислокационно-кинетического подхода, основанного на уравнениях, описывающих эволюцию средней плотности дислокаций в материале с ростом сдвиговой деформации, теоретически исследованы размерные эффекты, которые связаны с влиянием на деформационное упрочнение образца среднего размера зерен $d_{s}$ и толщины $D$ и обусловлены зависимостью членов кинетического уравнения от $d_{s}$ и $D$. Установленная принятым способом с помощью соотношения Тейлора и подтвержденная экспериментально связь между напряжением течения $\sigma$ и степенью деформации $\varepsilon$ использована для анализа деформационного упрочнения плоских образцов двумерных поликристаллов $\mathrm{Al}$ высокой чистоты с различным размером зерна в интервале $\sim 50$ мкм $<d_{s}<\sim 1$ мм и различной толщиной в интервале $\sim 50$ мкм $<D<\sim 1$ мм при одноосном растяжении с постоянной скоростью деформации при умеренных температурах. Найдено, что зависимость условного предела текучести $\sigma_{0,2}$ от размера зерна $d_{s}$ практически исчезает при $d_{s}>300$ мкм. Обнаружено, что значения $\sigma_{0,2}$ и коэффициента деформационного упрочнения $\theta=d \sigma / d \varepsilon$ убывают с ростом толщины $D$ образца. Эти убывающие зависимости сменяются возрастающими при увеличении степени деформации. Напряжение $\sigma$ и коэффициент $\theta$ возрастают с увеличением отношения $D / d_{s}$ на всех этапах деформирования.

\section{ДЕФОРМАЦЙНЕ ЗМІЦНЕННЯ ПЛОСКИХ ЗРАЗКІВ ДВОВИМІРНИХ ПОЛІКРИСТАЛІВ АІ ВИСОКОЇ ЧИСТОТИ}

\author{
С.Ю. Бадіян, А.Г. Тонкопряд, С.В. Фтьомов, О.В. Шеховцов
}

3 використанням дислокаційно-кінетичного підходу, який грунтується на рівняннях, що описують еволюцію середньої густини дислокацій в матеріалі зі зростанням зсувної деформації, теоретично досліджені розмірні ефекти, які пов'язані з впливом на деформаційне зміцнення зразка середнього розміру зерен $d_{s}$ і товщини $D$ і зумовлені залежністю членів кінетичного рівняння від $d_{s}$ i $D$. Встановлений прийнятим способом за допомогою співвідношення Тейлора і підтверджений експериментально зв'язок між напруженням плину $\sigma$ і ступенем деформації $\varepsilon$ використано для аналізу деформаційного зміцнення плоских зразків двовимірних полікристалів Al високої чистоти з різним розміром зерна в інтервалі $\sim 50$ мкм $<d_{s}<$ $\sim 1$ мм і різною товщиною в інтервалі $\sim 50$ мкм $<D<\sim 1$ мм при одновісному розтягуванні 3 постійною швидкістю деформації при помірних температурах. Знайдено, що залежність умовної границі плинності $\sigma_{0,2}$ від розміру зерна $d_{s}$ практично зникає при $d_{s}>300$ мкм. Виявлено, що значення $\sigma_{0,2}$ і коефіцієнта деформаційного зміцнення $\theta=d \sigma / d \varepsilon$ зменшуються із зростанням товщини $D$ зразка. Ці спадні залежності перетворюються на зростаючі при збільшенні ступеня деформації. Напруження $\sigma$ і коефіцієнт $\theta$ зростають зі збільшенням відношення $D / d_{s}$ на всіх етапах деформування. 